\title{
Limnology of natural systems for wastewater treatment. Ten years of experiences at the Experimental Field for Low-Cost Sanitation in Mansilla de las Mulas (León, Spain)
}

\author{
Eloy Bécares
}

Area de Ecología. Facultad de Biología. Universidad de León. 24071 León. Spain

Telf: 987291568 Fax: 987291409 , e-mail: degebm@unileon.es

\begin{abstract}
The first experimental field in Spain for low-cost wastewater treatment was constructed in 1998 in Mansilla de las Mulas (León). The project was funded by the Diputación de León and was run scientifically by the Department of Ecology at the University of León until 1999. The objective of the field was to compare performances and to study the biological fundamentals of systems such as constructed wetlands and algal ponds which had been adapted for wastewater treatment in rural areas. The experiences carried out on constructed wetland systems proved that macrophytes had a significant role in the treatment of diluted wastewaters. The role of vegetation varied depending on the technology used, being important for organic matter removal in free water surface systems, whereas plants were only significant for nutrients and faecal bacteria in subsurface flow systems. There were no differences among plant species in the performance of free water surface systems. Algae-based systems such as high rate algal ponds proved to be a highly efficient technology for wastewater disinfection. Studies on decay and inactivation of faecal bacteria and parasites (helmiths and protozoan oocysts) demonstrated for the first time that the physico-chemical conditions created by the algae are powerful mechanisms for pathogen destruction. Wastewater treatment plants are technologically-confined ecosystems in which limnological studies should be further encouraged both examining basic knowledge on natural species and processes and leading to a better understanding of the biological foundations for their design and operation.
\end{abstract}

Key words: wastewater, natural systems, constructed wetlands, high rate algal ponds, macrophytes, algae, nutrients, faecal bacteria, helminths, protozoa.

\section{RESUMEN}

La Universidad de León estableció en 1998 un proyecto de investigación con la Diputación Provincial cuya principal materialización fue la construcción del primer campo experimental en depuración de bajo coste en nuestro país. El objetivo del campo experimental fue el de estudiar, a escala experimental, diferentes procesos de bajo coste, entre ellos los humedales construidos y los lagunajes de alta carga. El presente trabajo resume los principales resultados de las investigaciones realizadas después de diez años de experiencias. Las plantas demostraron tener un papel significativo en humedales que tratan aguas residuales diluidas. Dicho papel fue diferente dependiendo de la tecnología. En sistemas de flujo sub-superficial las plantas demostraron influir significativamente sobre la eliminación de nutrientes y bacterias fecales, sin embargo en sistemas de flujo superficial dicho efecto fue insignificante, siendo sin embargo importante sobre la eliminación de materia orgánica. La especie de planta utilizada demostró no ser una variable importante en el funcionamiento de los sistemas de flujo superficial. Los experimentos realizados en lagunajes de alta carga demostraron que las condiciones físico-químicas creadas en dichos sistemas eran responsables de la inactivación del 50-90\% de los organismos patógenos e indicadores fecales estudiados. Los tratamientos biológicos de aguas residuales deben entenderse como ecosistemas tecnológicamente confinados en los que el conocimiento de su estructura y funcionamiento es aún excesivamente escaso en comparación con la importancia que representan para el medio ambiente.

Palabras clave: aguas residuales, sistemas naturales, humedales, lagunajes de alta carga, algas, macrófitos, nutrientes, bacterias fecales, parásitos, protozoos. 


\section{INTRODUCTION}

The biology of wastewater treatment plants is an important aspect of applied limnology. It includes a wide variety of aquatic organisms, from viruses to fishes, and their interactions and processes in relation to the fate and degradation of conventional and industrial water pollutants. Unfortunately, limnologists have paid much less attention to this field than chemical or civil engineers, and even today much of the biological research in this field is not performed by limnologists.

Wastewater treatment plants are technicallyconfined ecosystems in which design and operational variables have to be carefully controlled for the adequate selection of the organisms responsible for pollutants removal. Wastewater treatment plants are biotechnological reactors working under the same principles of other reactors (e.g. antibiotics production) with some important differences. First, they are biologically open systems. The continuous input of propagules is an important process for the system. The second aspect is that the quantity and quality of food (i.e. wastewater) is highly variable.

Wastewater treatment was also of interest for Ramon Margalef, who described them as "forced ecosystems" in which an intensification of processes occurs with a production in excess of their organisms (Margalef 1983). These systems have contributed to scientific knowledge in important aspects of microbial ecology and taxonomy, for instance of filamentous bacteria, nitrogen and phosphorus biological removal or protozoan ecology and taxonomy (Seviour \& Blackall 1999).

Wastewater treatment systems can be classified depending on their electric requirements and maintenance costs in one of two types. The "conventional systems" (activated sludge, biofilters) require a substantial number of pumps, aerators or other devices for their functioning. The second types are "low-cost systems" (trickling filters, stabilization ponds, constructed wetlands). In the latter type, minimum electric requirements and maintenance costs are necessary, although a much larger surface is required for their installation. These characteristics make low-cost systems a sustainable option in most rural areas. The re- search on their biological foundations is an important objective for applied limnology. As the scientific coordinator of the activities carried out at the Experimental Field for Low-cost sanitation in Mansilla de las Mulas from 1988 to 1999, here I present the main outcomes of the research carried out by the group during that time.

\section{THE EXPERIMENTAL FIELD}

In 1988 I was asked to propose ideas on how to manage the funds that the Diputación Provincial de León was planning on investing in wastewater treatment studies. The knowledge gained at that time in one of the first masters in Spain on Environmental Engineering at the Cantabria University, the limnological background of the Ecology Department at León University, and the fact that the Diputacion is an administrative body focused on promoting the development of rural areas, gave me the idea of proposing the construction of the experimental field, the first in Spain, to compare performances, economic costs and the biological fundamentals of lowcost wastewater treatment plants. No studies were available at that time on low-cost wastewater treatment systems and specially, on the biological basis of processes occurring in them. The location of the field was decided among villages surrounding the city of León on the following criteria: i) the proximity to the University of León, ii) the availability of a municipal area large enough for construction, iii) the vicinity to the area of a sewage system with enough flow for the experiments, and iv) the absence of industrial or heavily loaded wastewaters.

Climatic conditions in León province are a limiting factor for the design of wastewater treatment plant. Low temperatures in winter (mean temperature of the coldest month: $5^{\circ} \mathrm{C}$ ) means systems must be larger than in other parts of Spain. Moreover, wastewater is much diluted in our rural areas as a consequence of the deficient construction of sewers and the entrance of water from urban wells. Also, wastewater is recycled for use, either directly from the sewer or indirectly by using water from polluted rivers and streams. Thus, the study of 


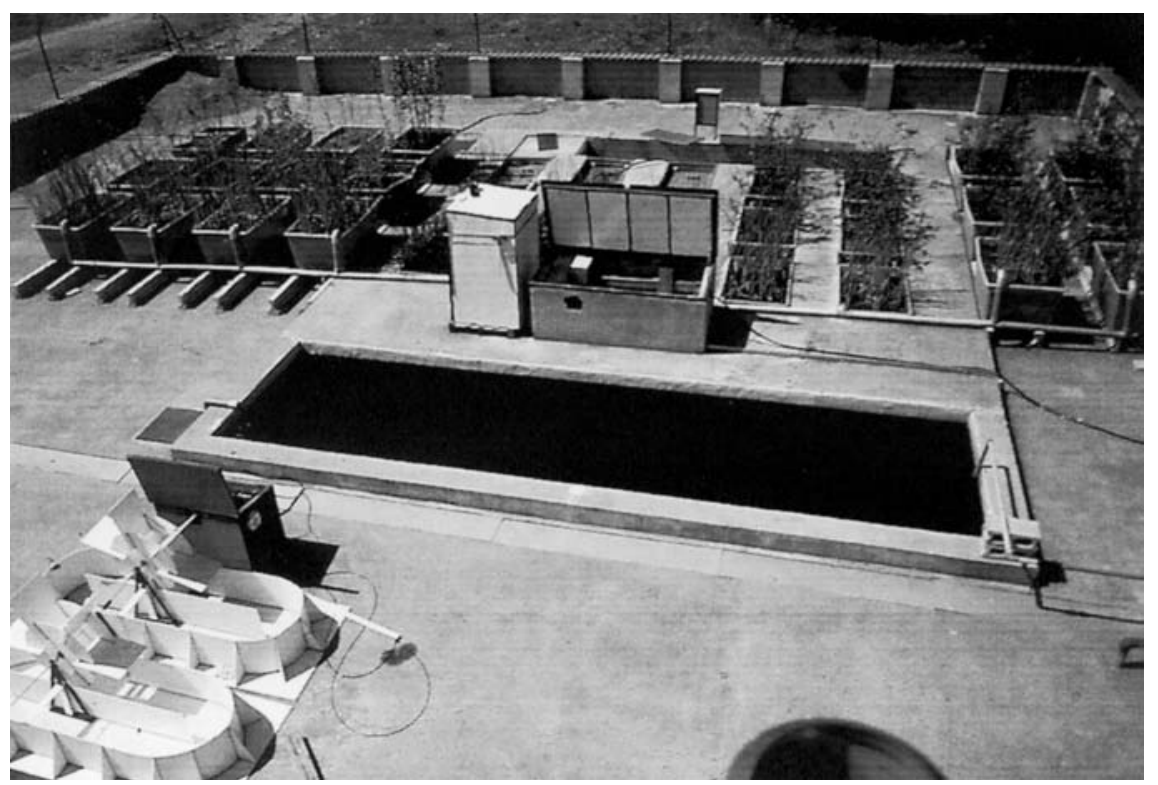

Figure 1. A view of the experimental field. High rate algae ponds in the bottom left. Stabilization pond in the middle and pilot tanks for constructed wetlands research on the top. Vista del campo experimental. Lagunajes de alta carga (parte inferior), lagunaje convencional de maduración (centro) y tanques piloto para experimentación con macrófitos acuáticos (parte superior).

the use of low-cost systems is warranted. Having in account previous considerations, the systems selected for experimentation fulfilled the following requirements: i) to be low cost systems with regard to operation and management, ii) they should be an adequate technology considering the climatic conditions in León province, iii) they should priorize the study of systems with good pathogen removal efficiency since wastewater reuse is a common practice in rural areas. I outlined the construction project with advice from the Departments of Environmental Engineering at the Universities of Cantabria and Polytechnic University of Barcelona and the Fondation Universitaire Luxembourgeoise. The construction project was finally designed in collaboration with the engineer from the Diputacion, César Roa. I decided first on a macrophytebased system due to the scientific background on aquatic plants available at the Department of Ecology, through the expertise of Drs. Camino and Margarita Fernández-Aláez. The experimental layout was based on that previously built by Radoux (Radoux \& Kemp 1982) in Viville (Belgium), and adapted to our particular conditions (Bécares 1989, Bécares et al. 1989). Other pilot-plant systems considered were a conventional facultative pond and a high rate algal pond (Fig. 1).

\section{APPLICATION OF CONSTRUCTED WETLANDS FOR WASTEWATER TREATMENT}

Constructed wetlands are based on the use of plants for the treatment of wastewater. Depending on the type of plants, the systems can include submerged plants (limnophytes, e.g. Myriophyllum spp., Ceratophyllum spp.), emergents (helophytes, Typha spp., Scirpus spp., Phragmites spp.) or floating plants (pleustophytes, Lemna spp., Eichhornia spp., Salvinia spp.). Because of the presence of surface water, the systems are classified as free-water surface (FWS) systems, in which a small depth of water (approximately $25-30 \mathrm{~cm}$ ) is maintained on the top of the soil, or subsurface flow (SSF) when water is a few centimetres below the soil level. According to flow type the systems are classified as horizontal or vertical flow systems. The combination of plant species and flow types has produced different technologies. The most common combine FWS with horizontal flow or SSF with horizontal or vertical flow. Detailed descriptions on these technologies can be found in several books and manuals (Hammer 1989, Moshiri 1993, Reed et al. 1995, Kadlec \& 
Knight 1996, Vymazal et al. 1998, Young et al. 1998, Kadlec et al. 2000). An up-to-date synthesis on these systems can be found in García J. et al. (2004). The first experiences in Spain on constructed wetlands for wastewater treatment were carried out in Murcia in the 80's using Phragmites in small tanks (Moreno 1989), followed by our work in Mansilla de las Mulas. At present there are about ten different groups in Spain working on the subject. The experiments conducted by García and collaborators are probably the most widely embracing (e.g. García J. et al. 2003, 2004)

\section{Have plants a significant role in constructed wetlands for wastewater treatment?}

The removal of organic and inorganic matter and bacteria from wastewater carried out by macrophytes has been explained through several mechanisms, such as sedimentation, mechanical filtration or nutrient assimilation by plants. Their roots may also serve as substrates for attached bacteria degrading and taking up nutrients and organic carbon (Brix, 1995). The latter process is favoured by oxygen release into the rhizosphere (Gersberg et al., 1986), and by plant exudates (Stengel, 1985). Despite this evidence, there is still controversy about the mechanisms of functioning of macrophytes for wastewater treatment in constructed wetlands. Some researchers have found wastewater treatment is improved in the presence of macrophytes (Rogers et al. 1991, Farahbakhshazad et al. 1995), while other studies have not detected significant differences in treatment results between planted and unplanted systems (Tanner et al., 1995). Nevertheless, comparisons between studies are difficult because they utilize diverse aquatic plant species, wastewaters and flows. One of our first objectives was therefore to test if plants had any significant role under the climatic conditions and wastewater characteristics in the province of León. Experiments were carried out in both FWS and SSF systems. Further details on the experiments and results are available in Ansola (1994) and García (2002).

\section{Organic matter and nutrient removal in subsurface flow systems}

SSF pilot-scale tanks $0.6 \mathrm{~m}^{3}$ in volume and with a surface of $1.1 \mathrm{~m}^{2}$ were planted with Scirpus lacustris growing on siliceous gravel. These systems were compared with treatments in which $S$. lacustris was grown in hydroponic culture, and with only gravel. The average diameter of gravel was $6 \mathrm{~mm}$, and porosity was calculated as $35 \%$. Two replicates of each treatment were used and all received the same wastewater. Hydroponic cultures were designed to work under plug-flow hydraulic regime by means of deflectors, and plants were supported using a small roll of garden net of $2 \mathrm{~cm}$ pore. Details on the experiments and results are available in Soto et al. (1999a, 1999b, 2000).

\section{Organic matter and suspended solids}

Plants do not take up organic matter but foster the growth of organisms in the rhizosphere which could help on such task (Brix 1994). In our experiments, removal rates for biological oxygen demand $\left(\mathrm{BOD}_{5}\right)$ and suspended solids (SS) were slightly higher in summer than winter but no statistically significant differences were found when comparing winter/summer or planted/unplanted conditions. In accordance with other authors (Tanner et al. 1995), absence of differences between tanks could be due to two reasons. First, solids (organic matter) accumulate in the first third of the system, mostly at the head of the tanks (Tanner \& Sukias 1995). Therefore, efficiency is potentially independent of plant presence. Second, BOD loads were very low, below $3 \mathrm{~g} / \mathrm{m}^{2} \mathrm{~d}$. Tanner et al. (1995) found this value to be the limit for detecting significant plant effects on BOD removal.

\section{Nitrogen. Ammonia}

A strong positive correlation was found between ammonia surface loading and removal rate (Soto et al. 1999a, 1999b). Removal rate was significantly higher $(\mathrm{P}<0.05)$ in planted tanks and also higher in summer than winter. Planted tanks removed $50 \%$ more ammonia than unplanted under winter conditions $\left(0.145 \mathrm{~g} / \mathrm{m}^{2} \mathrm{~d}\right.$.), and about $63 \%$ 
more in summer conditions $\left(0.297 \mathrm{~g} / \mathrm{m}^{2} \mathrm{~d}\right)$. This means that plant activity in summer was only responsible for $13 \%$ of the ammonia uptake (i.e. $0.152 \mathrm{~g} / \mathrm{m}^{2} \mathrm{~d}$ ), while other mechanisms unrelated to plant uptake but linked to plant presence, were responsible for the rest of the removal observed.

\section{Nitrogen. Nitrate}

Nitrification effectively occurred in both planted and unplanted tanks. Unplanted tanks were marginally more effective than those with plants in the removal of nitrate (differences were not statistically significant). The ratio $\mathrm{C}: \mathrm{N}$ (as BOD5:TN) was 2.42 in winter, and 3.55 during summer, high enough for denitrification to occur (Radtke, 1995). Nitrogen accumulation by plants was calculated in about $30 \%$ of the TN removed into the planted system, including the $\mathrm{N}$ accumulated in submerged parts, while the remaining $70 \%$ was likely removed by the microbial pool and lost through denitrification (Soto et al. 1999a).

\section{Phosphorus}

It is generally accepted that the mechanisms for phosphorus removal are more related to gravel surface processes, such as physical adsorption and chemical precipitation by $\mathrm{Ca}$ or $\mathrm{Fe}$ (see, for example, Nichols, 1983; Richardson, 1985; Faulkner and Richardson, 1989), than to biological processes, such as uptake by plants and microorganisms. However, and similarly to that found by Faulkner and Richardson (1989), the comparison between planted and unplanted systems showed that the removal rate of reactive phosphorus (SRP) and the removal efficiency were higher in planted than unplanted tanks. According to this, macrophytes were directly involved in the removal of $29 \%$ of TP in winter and $47.3 \%$ in summer (i.e. 0.024 and $0.057 \mathrm{~g} / \mathrm{m}^{2} \mathrm{~d}$ removed, respectively). These differences were statistically significant in summer.

\section{The effect of plants in free-water surface flow systems}

In systems with subsurface water flow, substrate hydraulic conductivity is an important design parameter. Wastewater interacts directly with the rhizosphere, and roots have additional functions apart from being the physical support for the biofilm. Nevertheless, in FWS systems, the hydraulic conductivity of the gravel bed and therefore the role of the rhizosphere is negligible (Kadlec and Knight, 1996). The main role of macrophytes is to provide additional surface for the development of a biofilm on the submerged parts of plants. Comparing planted and unplanted tanks, Ansola et al. $(1993,1995)$ proved that planted tanks were significantly different from control plots with regards to $\mathrm{DBO}, \mathrm{COD}$ and total phosphorus, but no differences were found between planted and unplanted tanks with regards to nitrogen forms (ammonia, nitrates, organic nitrogen) nor phosphates. Differences between FWS and SSF in the type of substances removed (nutrients in SSF, organic matter in FWS) are evidence that plants have a passive role in the superficial-flow systems, acting as a physical support for bacterial growth on their submerged leaves and stems.

\section{Mechanisms responsible for bacteria removal in constructed wetlands}

Similarly to previous researches (Gersberg et al. 1990a, Rivera et al. 1995, Tanner et al. 1995, Loveridge et al. 1995), from differences between planted and unplanted systems it can be concluded that macrophytes also play an active role in the removal of microorganisms from wastewater. Rooted biofilms provide a better substrate than gravel surfaces for microbial activity (Loveridge et al. 1995). Constructed wetlands are more efficient than conventional systems in the removal of bacteria but generally less efficient than stabilization ponds (García \& Bécares 1997). The comparison of planted and unplanted systems generally showed a higher rates of bacteria removal in the presence of plants, although results were highly variable and were dependent on plant type, hydraulic design and wastewater characteristics (Hammer 1989, Tanner et al. 1995).

Several mechanisms have been proposed, and on occasion demonstrated, to be responsible for bacteria removal. Oxygen production and bacte- 
rial activity in the rhizosphere (Brix 1987, 1997), sedimentation, filtration and adsorption (Gersberg et al. 1989, Williams et al. 1995) are commonly cited mechanisms in the literature. Decamp \& Warren (1998) and Rivera et al. (1995) have pointed bacterivory as a key mechanism in CW, as microfaunal densities and predatory activity were higher in the presence of plants in their experiments. Excretion of antibacterial compounds by plants is another controversial mechanism frequently cited in the literature, but not yet clearly proved. Plants modify the soil microenvironment and probably release substances which enhance the development of specialized bacterial on its rhizosphere (Hatano et al., 1993). Commonly cited papers, such as those by Seidel $(1955,1976)$, Gopal \& Goel (1993), Ottová et al. (1997) and others have not been able to prove a direct effect of plants on bacteria inhibition but have found that plant presence is related to higher bacteria reductions. There is evidence showing that some plants produce secondary metabolites with antibacterial properties (e.g. Dellagreca et al. 2001), although their role in wastewater treatment has still to be proved.

An important part of our studies at the Experimental Field were focused on determining and quantifying the mechanisms involved in bacteria and pathogen removal by constructed wetlands. Studies comparing the role of Scirpus lacustris in planted and un-planted subsurface flow tanks (García et al. 1999, Soto et al. 2000) showed that planted tanks were more efficient at removing microbes (up to $99.9 \%$ ) than unplanted tanks. There were statistical differences between planted and control conditions $(p<0.01)$ for total coliforms, faecal streptococci and total heterotrophs, and removal rates were higher in summer than winter. Antibacterial activity potentially exerted by plants was not detected by using filtered effluents from planted tanks as dilution water for total bacterial growth in the influent (García et al. 2004). Predation, as a potential mechanism for bacteria removal was also evaluated in these systems (García et al. 2004). Decamp et al. (1999) found a higher ciliate abundance and predatory activity in plan- ted than unplanted gravel wetlands. In our tanks, results showed that the abundances of ciliates and flagellates, the only bacterivorous organisms found, were much lower than reported in other similar systems (Decamp et al. 1999, Panswar and Chavalparit 1997). Differences in abundance in planted and unplanted tank were statistically significant for flagellates but not for ciliates. The presence of plants increased protozoan abundance, which could be another reason for the higher bacteria removal in planted systems (García et al. 2004).

\section{Do the plant species matter?}

It is well known that different plant species have different resource requirements and rates of matter processing. A question here was if there were differences among helophytes with regard to their processing efficiency on nutrients or organic matter pollution. Scirpus lacustris, Typha angustipholia, Iris pseudacorus, Phragmites australis and a control without plants were simultaneously grown in small tanks with surface flow hydraulics. Ansola et al. (1994) did not find differences among plant species for all variables studied with the exception of phosphates for Iris pseudacorus, which presented significantly higher removals compared to Typha and Phragmites. In other experiment (Ansola 1994), compared three-way combinations of plants (Scirpus-Iris-Phragmites, Typha-Iris-Scirpus, Typha-Scirpus-Phragmites) growing in separate tanks. Results showed no differences among combinations of plants for nutrients or organic matter. Concerning faecal indicators and pathogen removal, López \& Bécares (1993) found that Scirpus lacustris had higher bacteria removal rates than the aforementioned species, as shown by most faecal indicators used.

\section{ALGAE-BASED SYSTEMS FOR WASTEWATER TREATMENT}

A high rate algal pond (HRAP) was the algaebased system selected for testing under the aforementioned climatic conditions in León. HRAP 
is a low-cost wastewater treatment system designed to achieve two goals: the secondary treatment of wastewater and the production of algal biomass. The HRAP is a combination of intensified oxidation pond and algal reactor. Algae supply the oxygen needed for the bacterial degradation of organic matter, while bacteria supply mineral compounds excreted to the algae for their nutrition. The HRAP is characterized by shallow depths, mechanical mixing and short residence times, implying smaller surface areas than those of conventional stabilization ponds (Fallowfield \& Garret 1985). HRAP systems were first designed for wastewater treatment by Oswald $(1963,1988)$, and thereinafter were used in other parts of the world. Particulary worthy of notice are the projects by Shelef in Israel (Shelef \& Azov, 1987). The first experiences in Spain were carried out in the extinct Centro de Investigaciones del Agua in La Poveda (Arganda del Rey), where studies on algal biomass production were carried out in outdoor pilot plants (Velasco et al. 1988). Studies on this topic continued into the early nineties at the Polithecnic University of Barcelona (UPC; García J., 1996). Our experiences on HRAP systems followed the experimental layout and pilot plant characteristics previously developed at the UPC.

The complete description of performances and details on the experiments and their seasonal and diurnal patterns are described in González 1999 and González et al. (1994, 1999, 2000, 2001) and Araki et al. (2000, 2001). Experiments tested several hydraulic detention times (10, 5 and 3 days) under both summer and winter conditions. A water velocity of $15 \mathrm{~cm} / \mathrm{sec}$ could be achieved in the system by using paddle wheels at a rotational speed of 3 r.p.m. A depth of water of $30 \mathrm{~cm}$ was maintained constant during the study. The best results for $\mathrm{COD}, \mathrm{BOD}_{5}$ and solids removal were obtained with a hydraulic detention time of 3 days. Algal populations were dominated by blooms of Monoraphidium contortum followed by Scenedesmus spp. HRAP was therefore considered an adequate system for the wastewater treatment in the León area, being potentially appropriate for the treatment of heavily polluted wastewater such as that from pig farms, which are abundant in the area.

\section{The pathogen removal mechanism in algae-systems. The role of physico-chemical conditions}

Evidence on disease transmission associated with raw wastewater reuse, points most strongly to the helminths and protozoa parasites as the number one problem, with only limited transmission of bacterial and virus disease (Shuval 1991). The very low doses required to produce infection (Boutin 1982), their cosmopolitan distribution and their long persistence in the environment (Feachmen et al, 1983) make these organisms the main problem in wastewater reuse, mainly in rural areas. Because of their tough wall, these parasites are also extremely resistant to disinfection with chlorine, monochloramine and many other chemicals (Campbel et al. 1995, Fayer et al. 1996). In recent years, various studies in different countries have shown that one of the most important waterborne pathogen is Cryptosporidium parvum, a protozoan parasite causing diarroheal disease in a wide range of vertebrates including humans (O’Donoghue 1995). International guidelines strongly recommend the use of low-cost, highly efficient pathogen removal systems for wastewater treatment and stabilization ponds systems are the most efficient for their removal (Schwardzbord et al. 1989, Shuval 1991). High rate algal ponds follow basically the same removal mechanisms than stabilization ponds. Both are highly efficient according to faecal bacteria indicators (García \& Bécares 1997). However, the precise mechanisms underlying the removal of parasites in these systems are still unclear (El Hamouri et al. 1994). Several experiments were carried out at the Experimental Field with an aim to discriminating the role of ionic conditions as a mechanism for helminths and protozoa parasites decay, excluding other removal factors like sedimentation or predation. Further details on the experiments and the results obtained are presented in Araki et al. (2000, 2001). 
The viability of Cryptosporidium parvum oocysts and Parascaris equorum eggs were studied in two experimental pilot-scale High Rate Algal ponds (HRAP) working in parallel during hydraulic retention time (HRT) of 3 and 10 days. Semi-permeable bags of cellulose (14000 daltons pore size) were used to determine the effect of the physico-chemical environment on the infectivity of the oocysts. Semi-permeable bags only allow the exchange of small ions and water between the reactor and the eggs. Viability was tested using the method used by Caseres et al. (1987) for helminths and neonatal NMRI mice inoculated intragrastricaly with treated and untreated $C$. parvum oocysts. Results revealed that inactivation of oocysts by HRAP was higher than in conventional wastewater treatment systems. The HRAP physico-chemical conditions were responsible for more than $97 \%$ of the reduction of infection cases in mice. The lack of differences between the two retention times tested suggests that oocysts lose their infectivity shortly after contact with the water environment. With regard to the helminths, a $60 \%$ reduction in viability was achieved after 4 days exposure to conditions in the HRAP, reaching a $90 \%$ reduction after 10 days. The effect of ions and general osmotic conditions on the viability of nematode eggs under the HRAP water environment was responsible for 50-60 \% of egg mortality. This implies that mortality due to the ionic environment in the HRAP could be more important than physical retention and other removal factors potentially involved.

\section{CONCLUSIONS}

Main outcomes after ten years of research can be summarized as follows: i) Plants have a significant effect on wastewater treatment when treating diluted wastewater, and are a necessary element of the treatment system. Nevertheless, their role depends on the type of treatment process. Plants are relevant to nutrient removal but not to that of organic matter in subsurface flow systems, whereas the opposite occurs in freewater surface systems, ii) the type of species used in FWS systems is not important; all spe- cies had good performances, iii) plants did not show a direct effect on bacteria removal but demonstrated an indirect effect through the creation of an hostile rhizosphere environment in turn stimulating the growth of bacterivorous populations, iv) high rate algal ponds are an adequate technology for wastewater treatment, specially when bacteria removal is an important treatment objective, v) physico-chemical conditions created by the metabolism of algae is the main mechanism responsible for the inactivation and decay of bacteria and parasites cysts.

\section{ACKNOWLEDGEMENTS}

This paper is especially dedicated to Félix Soto, Juan Manuel González and My Smail Araki, whose hard and enthusiastical work made possible the functioning of the Experimental Field. It is a tragedy of our university system that reasons other than scientific excellence very often prevail, driving away good researchers. The University of León established an agreement with the Diputación Provincial entitled: Estudio comparado de diferentes sistemas de depuración de bajo coste. Asesoramiento y análisis de la eficacia del Plan de Saneamiento de la Provincia de León. I would also like to thank the official director of this agreement, Dr. Estanislao Luis Calabuig, for his good management of institutional relations, and all students and University staff which were involved in the project, and specially my thanks to Gemma Ansola, Mercedes García, Gloria López, María J. López and Camino and Margarita Fernández-Aláez. This project was funded by the Diputación Provincial de León thanks to the good insight of its former President D.Alberto Pérez, and also thanks to the dedication of D. César Roa and D. Jaime Martino, who invested in the "frog's pond" much of their valuable time during the years of the study.

\section{REFERENCES}

ANSOLA, G. 1994. Sistemas de experimentación con macrófitos como mecanismo de depuración 
de la contaminación acuática y evaluación de los procesos de transformación en ambientes rurales. Ph.D. Thesis. University of León. 236 pp.

ANSOLA, G., E. de LUIS, \& C. FERNÁNDEZ. 1993. Evaluation of the treatment capacity of an emergent macrophyte experimental plant for low density populations in the initial working stages. Procc. $2^{\text {nd }}$. Internat. Conf. Small Wastewater Treatment Plants. Trondheim, Norway: 367-374.

ANSOLA, G., C. FERNÁNDEZ, \& E. de LUIS, 1995. Removal of organic matter and nutrients from urban wastewater by using experimental emergent aquatic macrophyte system. Ecolog. Engineering, 5: 13-19.

ARAKI, S., J. M. GONZÁLEZ, E. DE LUIS, \& E. BÉCARES. 2000. Viability of nematode eggs in HRAP. The effect of the physico-chemical conditions. Wat. Sci. Tech., 42 (10/11): 371-374.

ARAKI, S., S. MARTÍNEZ-GÓMEZ, E. BÉCARES, E, LUIS \& F. ROJO. 2001. Effect of high-rate algal ponds on viability of Cryptosporidium parvun oocystis. Appl. Envirom. Microbiol., 67: 3322-3324.

BÉCARES, E. 1989. Estudio sobre la utilización de plantas en el tratamiento de aguas residuales. Propuesta de un sistema experimental. ESICCP. Universidad de Cantabria. 20 pp.

BÉCARES, E. 2004. Función de la vegetación y procesos de diseño en humedales construidos de flujo superficial y sub-superficial. En: Nuevos criterios para el diseño y operación de humedales construidos. J. García, J. Morató y J. M. Bayona (eds.).: 51-63 Ediciones CPET, UPC, Barcelona

BÉCARES, E., G. ANSOLA, \& C. FERNÁNDEZ. 1989. Diseño de una planta experimental de macrófitos acuáticos para la depuración de las aguas residuales. Actas PROMA89, I: 199-210

BOUTIN, P. 1982. Risques sanitaires provenant de l'utilisation d'eaux poluées ou de boues de la station d'épuration en agriculture, T.S.M., 12 : 547557.

BRIX, H. 1987. Treatment of wastewater in the rizosphere of wetland plants.- The root zone method. Wat. Sci. Tech., 19: 107-115.

BRIX, H. 1994 Functions of macrophytes in constructed wetlands. Wat. Sci. Tech., 29: 71-78.

BRIX, H. 1995. Use of subsurface flow constructed wetlands for wastewater treatment - an overview. In: Natural and constructed wetlands for wastewater treatment and reuse - Experiences, goals and limits. R. Ramadori, L. Cingolani y L. Cameroni (eds.).: 103-111. Perugia.
BRIX, H. 1997 Do macrophytes play a role in constructed wetlands? Wat. Sci. Tech., 35(5): 11-17.

CAMPBELL, A. T., L. J. ROBERTSON, M. R. SNOWBALL, \& H. V. SMITH. 1995. Inactivation of oocysts of C. parvum by ultraviolet irradiation. Wat. Res., 29: 11 2583-2586.

CASERES, A., A. M. XET, \& G. FLORES. 1987. Simplified methodology for helminth eggs counts and viability in organic fertilizer. Second project Meeting on use of Human waste in agriculture and aquaculture, Adelboden, Switzerland, 15-19 June.

DECAMP, O. \& A. WARREN. 1998. Bacterivory in ciliates isolated from constructed wetlands (reed beds) used for wastewater treatment. Wat. Res., 32: 1989-1996

DECAMP, O., A. WARREN, \& R. SÁNCHEZ. 1999. The role of ciliated protozoa in subsurface flow wetlands and their potential bioindicators. Wat. Sci. Tech., 40: 91-98.

DELLAGRECA, M., \& A. FIORENTINO, M. ISIDORI, \& A. ZARRELLI. 2001. Toxicity evaluation of natural and synthetic phenantrenes in aquatic systems. Environ. Toxicol. Chem., 20: 1824-1830.

EL HAMOURI, B., K. KHALLAYOUNE, K. BOUZOUBAA, N. RHALLABI, \& CHALABI 1994. High-rate algal pond performance in faecal coliforms and helminth eggs removals. Wat. Res., 28: 171-174.

FALLOWFIELD, H. J. \& M. K. GARRET. 1985. The treatment of wastes by algal culture. J. Appl. Bacteriol. Symp. Suppl., 4: 187-205.

FARAHBAKHSHAZAD, N., G. M. MORRISON, A. LARSSON, \& S. E. B.WEISNER. 1995. Effects of grain size on nutrient removal from wastewater in small-scale planted macrophyte system. In: Natural and Constructed wetlands for Wastewater Treatments and Reuse. Ramadori, R., Cingolani y L. Cameroni, L. (eds.): 143-150. Perugia.

FAULKNER, S. P. and RICHARDSON, C. J. 1989. Physical and chemical characteristics of freshwater wetland soil. In: Constructed wetlands for wastewater treatment. Municipal, industrial and agricultural. Hammer, D.A. (ed.): 41-73. Lewis Publishers, Chelsea, Michigan.

FAYER, R., T. GRACZYK, M. R. CRANFIELD, \& J. M. TROUT. 1996 Gaseous disinfection of Cryptosporidium parvum oocysts. Appl. Env. Microbiol., 62: 3908-3909.

FEACHMEN, R. G., D. J. BRADLEY, H. GARELICK, \& D. D MARA. 1983. Sanitation and disease: Health aspects of excreta and waste- 
water managment. John Wiley Pub. Chichester. New York. 215 pp.

GARCÍA, J. 1996. Eliminació de matèria orgànica $i$ nutrients en llacunes d'alt rendiment. $\mathrm{Ph}$. D. Thesis. Universitat de Barcelona (Spain). $301 \mathrm{pp}$.

GARCÍA, J., E. OJEDA, E. SALES, F. CHICO, T. PÍRIZ, P. AGUIRRE, R. MUJERIEGO. 2003. Spatial variations of temperatura, redox potential, and contaminants in horizontal flor reed beds. Ecol. Eng., 21: 129-142.

GARCÍA, J., J. MORATÓ, \& J. M. BAYONA. 2004. Nuevos criterios para el diseño y operación de humedales construidos. Ediciones CPET, Universidad Politécnica de Cataluña, Barcelona. $100 \mathrm{pp}$.

GARCÍA, J., P. AGUIRRE, R. MUJERIEGO, Y. HUANG, L. ORTIZ, \& J. M. BAYONA. 2004. Inicial contaminant renoval performance factors in horizontal flor reed beds used for treating urban wastewater. Wat. Res., 38: 1669-1678.

GARCÍA, M. 2002. Importancia de la rizosfera de los macrófitos acuáticos sobre la eliminación de bacterias y nutrientes en un sistema experimental de tratamiento de aguas residuales. Tesis Doctoral. Universidad de León. 311 pp.

GARCÍA, M., \& E. BÉCARES, 1997. Bacterial removal in three pilot-scale wastewater treatment systems for rural areas. Wat. Sci. Tech., 35: 197200.

GARCÍA, M., E. BÉCARES, F. SOTO, \& E. LUIS, 1999. Papel de los macrófitos en el tratamiento de las aguas residuales. I: Eliminación de bacterias. Tecnología del Agua, 185: 168-72.

GARCÍA, M., E. BÉCARES, \& F. SOTO. 2004. Are bacterial removal efficiencies enhanced by plants? An experimental study using Scirpus lacustris. Procc. $9^{\text {th }}$ Internat. Conf. Constructed Wetlands. Avignon, France. 4 pp.

GERSBERG, R. M., R. A. GEARHEART, \& M. IVES. 1989. Pathogen removal in constructed wetlands. In: Constructed wetlands for wastewater treatment: Municipal, Industrial and agricultural. D.A. Hammer (ed.): 431-445. Lewis Publ. Chelsea.

GERSBERG, R. M., B. V. ELKINS, S. R LYON, \& C. R. GOLDMAN. 1986. Role of aquatic plants in wastewater treatment by artificial wetlands. Wat. Res., 20: 363:368.

GERSBERG, R. M., S. R. LYON, R. BRENNER, \& B. V. ELKINS. 1990. Integrated wastewater treatment using artificial wetlands: A gravel marsh case study. In: Constructed wetlands for wastewater treatment. Hammer, D.A. (ed.): 145-152. Lewis Publications.

GONZÁLEZ, J. M. 1999. Estudio comparado de diferentes sistemas de lagunaje como mecanismo de depuración biológica de aguas residuales en plantas experimentales. Tesis Doctoral. Universidad de León. 285 pp.

GONZÁLEZ, J. M., M. S. ARAKI, E. BÉCARES, \& E. LUIS. 1999. HRAP application for wastewater treatment in northwest of Spain. th $^{\text {th }}$ Internat. Conf. Waste Stabilization Ponds. Marrakech (Marruecos). 8 pp.

GONZALEZ, J. M., E. BÉCARES, \& E. LUIS. 2001. Limnología de sistemas experimentales de lagunaje para el tratamiento de aguas residuales. Limnetica, 20: 267-277

GONZÁlEZ, J. M., E. BÉCARES, F. SOTO, \& G. ANSOLA. 1994. Comparison of waste stabilization ponds and high rate algal ponds (HRAP) in extreme continental climate zones. Procc. I Jornadas Internacionales Aguas Residuales Urbanas e Industriales, Sevilla (España), 4 pp

GONZALEZ, J. M., E. BÉCARES, F. SOTO, M. GARCIA, G. LÓPEZ, G. ANSOLA, \& E. LUIS. 2000. Diurnal changes in two algal ponds for wastewater treatment. Verh. Internat. Verein. Limnol., 27: 1-4.

GOPAL, B., \& U. GOEL. 1993. Competition and allelopathy in aquatic plant communities. Botanical Rev., 59: 155-210

HAMMER, D. A. 1989. Constructed wetlands for wastewater treatment, municipal, industrial, and agricultural. Lewis Publishers, Chelsea, Mi. 831 pp.

HATANO, K.,C. C. TRETTIN, C. H. HOUSE, \& A. G.WOLLUM. 1993. Microbial populations and decomposition activity in three subsurface flow constructed wetlands. In: Constructed wetlands for water quality improvement. G. A. Moshiri (ed.).: 541-548. Lewis Publications.

KADKEC, R. H., \& R. L. KNIGHT. 1996. Treatment wetlands. Lewis Press CRC, Boca Ratón. 893 pp.

KADLEC, R. H., R. L. KNIGHT, J. VYMAZAL, H. BRIX, P. COOPER, \& R. HABERL. 2000. Constructed wetlands for pollution control. Scientific and Technical Report 8. IWA Publishing, London. 156 pp.

LÓPEZ, M. J., \& E. BÉCARES. 1993. Primeros datos sobre la eliminación de bacterias en sistemas experimentales de depuración por macrófitos. Procc. III congreso de ingeniería ambiental. Vol II. 196-200. 
LOVERIDGE, R. F., J. M. WILLIAMS, C. M. HUGHES, S. EL-SHATOURI, J. MITCHELL, E. MAY, \& J. E. BUTLER. 1995. Changes in biofilm composition an the roots of Phragmites australis in gravel-based constructed wetlands. Procc. Natural and constructed wetlands for wastewater treatment and reuse - Experiences, goals and limits. R. Ramadori, L. Cingolani, L. Cameroni (ed.): 171-780. Perugia,

MARGALEF, R. 1983. Limnología. Ediciones Omega, Barcelona. 1010 pp.

MORENO, G. 1989. Depuración de aguas residuales urbanas de Cartagena con macrófitas en planta piloto. Estudio bioquímico y modelización. Tesis Doctoral. Universidad de Valencia. Valencia. $220 \mathrm{pp}$.

MOSHIRI, G. A. 1993. Constructed wetlands for water quality improvement. Lewis Publ. Chelsea. 632 pp.

NICHOLS, D. L. 1983. Capacity of natural wetlands to remove nutrients from wastewater. Journal WPCF, 55 (5): 495-505.

O'DONOGHUE, P. J. 1995. Cryptosporidium and cryptosporidiosis in man and animals. Int. J. Parasitol., 25: 139-195.

OSWALD, W. J. 1963. High rate pond in waste disposal. Development in Industrial Biotechnology, 4: 112-119.

OSWALD, W. J. 1988. Micro-algae and waste-water Treatment. In: Microalgal Biotechnology. M.A. Borowitza. \& L.J. Borowitzka. (eds.): 305-328. Cambridge University Press.

OTTOVÁ, V., J. BALCAROVÁ, \& J. VÝMAZAL. 1997. Microbial characteristics of constructed Wetlands. Wat. Sci. Tech., 30: 117-124.

PANSWAR, T., \& O. CHAVALPARIT, 1987. Water quality and occurrences of protozoa and metazoa in two constructed wetlands treating different wastewaters in thlailand. Wat. Sci. Tech., 36(12): 183-188

RADOUX M., \& D. KEMP. 1982. Approache écologique et experimentale des potentialités épuratrices de quelques hélophytes : Phragmites australis (Cav.) Trin. Ex Steud., Typha latifolia L. et Carex acuta L. Tribune Cebedeau, 465/466: 325-340.

RADTKE, R. 1995. Denitrifikation in horizontal durchströmten Pflanzenbeeten. Unpublished diploma Thesis, Technishe universität Berlin, F.G. siedlungswasser-wirtschaft. $125 \mathrm{pp}$.

REED S. R., R. W. CRITES \& J. E. MIDDLEBROOKS. 1995. Natural systems for waste management and treatment. McGraw-Hill, New York. $270 \mathrm{pp}$.
RICHARDSON, C. J. 1985. Mechanisms controlling phosphorous retention capacity in freswater wetlans. Science, 228: 1424.

RIVERA, F., A. WARREN, E. RAMIREZ, O. DECAMP, P. BONILLA, E. GALLEGOS, A. CALDERÓN, \& J. T. SANCHEZ. 1995. Removal of pathogens from wastewaters by the root zone method (R.Z.M.). Wat. Sci. Tech., 32(3): 211-218.

ROGERS, K. H., P. F. BREEN, \& A. J. CHICK. 1991. Nitrogen removal in experimental wetland treatment systems: evidence for the role of aquatic plants. Res. J. Wat. Pollut. Cont. Fed., 63: 934-941.

SCHWARTBORD, J., J. L. STIEN, K. BOUHOUM, \& B.BALEAUX, 1989. Impact of wastewater treatment on helminth eggs. Wat. Sci. Tech., 21: 295297.

SEIDEL, K. 1955. Die flechtbinse Schoenoplectus lacustris, Okologie, Morphologie und Entwirkung Bedeutung. PhD. Thesis Dissertation. Max Plank Institute, Germany.

SEIDEL, K. 1976. Macrophytes and water purification, In: Biological control of water pollution. In: J. Tourbier \& R. W. Pierson, (eds.).:109-121. University of Pennsylvania Press.

SEVIOUR, R. J. \& L. L. BLACKALL. 1999. The microbiology of activated sludge. Kluwer, Dordrecht. 360 pp.

SHELEF, G. \& Y. AZOV. 1987. High Rate Oxidation Ponds. The Israeli Experience. Wat. Sci. Tech., 19:249-255.

SHUVAL, H. I. 1991. The development of health guidelines for wastewater reclamation. Wat. Sci. Tech., 24: 149-155.

SOTO, F., M. GARCÍA, E. de LUÍS, \& E. BÉCARES. 1999a. Role of Scirpus lacustris in bacterial removal from wastewater. Wat. Sci. Tech. 40: 241-247.

SOTO, F., E. BÉCARES, M. GARCÍA, \& E. LUIS. 1999b. Papel de los macrófitos en el tratamiento de las aguas residuales. II: Eliminación de nutrientes. Tecnología del Agua, 185: 64-67

SOTO F., M. GARCÍA, \& E. BÉCARES. 2000. Seasonal differences in removal efficiencies using S. lacustris for wastewater treatment. $7^{\text {th }}$ Internat. Conf. Wetland Systems Water Pollution Control. $8 \mathrm{pp}$.

STENGEL, E. 1985. Perspektiven der nitratelimination in küstlichen Feuchtgebieten. Grundlagen und praxis naturnaher Klärverfahren. Sammelband des symposiums vom. Liebenburg. Verlagsgruppe Witzenhausen. $173 \mathrm{pp}$. 
TANNER, C. C., \& SUKIAS, J. P. 1995. Accumulation of organic solids in gravel-bed constructed wetlands. Wat. Sci. Tech., 32: 229-239.

TANNER, C. C., J. S. CLAYTON, \& M. P.UPSDELL. 1995. Effect of loading rate and planting on treatment of dairy farm wastewaters in constructed wetlands-I. Removal of oxigen demand, suspended solid and faecal coliforms. Wat. Res., 29(1), 17-26.

VELASCO J. L., M. F. COLMENAREJO \& M. ALVAREZ. 1985. Producción de biomasa de microalgas a partir de aguas residuales urbanas en balsas al aire libre. Actas VI Congreso Nacional de Química, 4: 587-594.
VIMAZAL, J., H. BRIX, P. F. COOPER, M. B. GREEN, \& R. HABERL. 1998. Constructed wetlands for wastewater treatment in Europe. Backhuys Pub., Leiden. 264 pp.

WILLIAMS, J., M. BAHGAT, E. MAY, M. FORD, \& J. BUTLER. 1995. Mineralisation and pathogen removal in gravel bed hydroponic constructed wetlands for wastewater treatment. Wat. Sci. Tech., 32: $49-58$

YOUNG, R., G. WHITE, M. BROWN, J. BURTON, \& B.ATKINS. 1998. The constructed wetlands manual. Department of Land and Water Conservation, New South Wales, Australia. 